\title{
Heritage and Empowerment of Local Development Players
}

\section{by Manuelina Maria Duarte Cândido}

\begin{abstract}
Manuelina Maria Duarte Cândido has been Professor of Museology at the Federal University of Goiás since 2009. She holds a degree in History from the State University of Ceará (1997), specialising in Museology (2000), a M.Sc. in Archaeology (2004) from the University of São Paulo and a Ph.D. in Museology (2012) from the Lusófona University of Humanities and Technologies, Lisbon, Portugal. She coordinated the Centre for Educational Action of the Centro Cultural São Paulo (2004) and directed the Museu da Imagem e do Som do Ceará (Ceará Museum of Image and Sound) (2007-2008). She is the author of several articles and presentations as well as three books on museology, the most recent of which is Gestão de Museus, um Desafio Contemporâneo. She is currently conducting postdoctoral research in museology at the University of the New Sorbonne, Paris III.
\end{abstract}

Will the recent drive to renovate museums become a third revolution in museology?

Many authors consider that the first revolution took place between about 1880 and the start of the $20^{\text {th }}$ century with the professionalisation of the field. The second revolution started in 1960, with the so-called New Museology (Davis, 1999; Van Mensh, 1992). At a certain point, the founders of the International Movement for a New Museology (MINOM), today an Affiliated Organisation of the International Council of Museums (ICOM), dissented and separated themselves from ICOM. In order to flourish, the museology movement distanced itself from ICOM, due to the organisation's more conservative approach. However, the movement has since found greater acceptance and attention within ICOM, or at least in some of its sectors. For instance, today we see the Museum International journal, now under the aegis of ICOM, dedicating its first issue to a single country - Brazil - which is at the cutting edge in a museological movement that is radically engaged with social change.

Many factors have contributed to this emphasis on Brazil: the new role of emerging countries in the global scene; the recent hosting of the $23^{\text {rd }}$ ICOM General Conference in Rio de Janeiro; and other important international events scheduled to take place in the country in the near future, such as the 2014 FIFA World Cup and the 2016 Olympic Games. In addition, the strength of Brazilian actions in terms of museum development models such as ecomuseums, community museums, street museums, indigenous museums, favela museums, route museums, neighbourhood museums and parade museums, among others, shows great imagination in the museum field (Chagas, 2011) and the desire to demonstrate that we are capable of attracting international attention. Other actions that are more or less identified with museological concepts such as Points of Memory, heritage education, Afro-Brazilian clubs and participatory 
inventories abound in this vast nation, creating an incomparable scene and one that is worthy of immediate attention.

This article explores the idea that every museum is a musealisation process, and that musealisation processes, even when they are being developed and are characterised by a unique and creative interpretation of the museological operational chain (safeguarding and communication of heritage), can be interpreted as museums, whether or not they are ultimately institutionalised (Duarte Cândido, 2014).

These initiatives have been the subject of particular attention in the Decade of Museological Heritage (2012-2022) adopted by the 2001 Ibero-American Ministers of Culture at the Asuncion Conference in Paraguay, a reference to the $40^{\text {th }}$ anniversary of the Santiago de Chile Round Table of 1972.

In this context, it is impossible to refer to heritage without relating it to local community empowerment because, according to Hugues de Varine, 'Local development, even if considered in its economic dimension, is primarily a question of players, and especially of local players' (de Varine, 2012, p. 18). The author goes on to say that 'heritage should be managed as closely as possible to the creators and owners of the heritage, so that it is not separated from life' (ibid., p. 19). He also states that heritage must be taken as a framework, a template or a resource for development. But the greatest value is in people. Heritage or collections serve as pretexts for the empowerment of local development players, and these people are considered not only in terms of their right to enter and visit museums, but also as leading players in the creation of future museums (Duarte Cândido and Lima, 2014).
Brazil has been prodigious in the generation of first-person memories and heritage assets, structuring discourses to address the anthropological notion of minimal otherness (Peirano, 1999). Beyond the best-known major urban centres, the country as a whole is a heritage and museological universe open to discovery and the exchange of experiences between scholars and professionals involved in the field of museums. Brazil spans 8.5 million $\mathrm{km}^{2}$, with a population of around 200 million, living in 5,561 municipalities. Cultural diversity has left a strong imprint on the country and demands that our memories and plural identities should be discussed. Those wishing to become acquainted with this reality must therefore be well prepared and have the time to cover great distances and address huge differences. A total of 3,118 museums has been mapped by the Brazilian Institute of Museums (IBRAM, 2011a), but only $21.9 \%$ of Brazilian municipalities contain museums. There remains a significant concentration of institutions in certain states and regions, especially on the coast, and in every state capital. This article seeks to show a more diverse situation and present other scenarios.

\section{Networks to promote dialogue}

A characteristic that has contributed to the strengthening of experiences and dissemination of information - always a challenge given Brazil's vast size - is that museological practice is largely based on state, municipal, regional or themed museum networks and systems, whether they are promoted by the government or at the initiative of civil society. The strongly associativist nature of community museums and ecomuseums is derived from the Brazilian Association of Ecomuseums and Community Museums (ABREMC), founded in 2004 during the $3^{\text {rd }}$ International Conference of Ecomuseums and Community Museums and the 
$10^{\text {th }}$ MINOM International Workshop. The formal establishment of ABREMC as a legal entity was a response to demand for representation of ecomuseums and community museological processes by the Management Committee for Brazilian Museums, under the control of the Ministry of Culture. A number of other networks play key roles in dialogue at a state-wide level and with each other, such as the Ceará Community Museums Network; the Rio Grande do Sul Network of Points of Memory, and Memory and Social Museology Initiatives; the Rio Grande do Norte Points of Memory Network; the Pará Points of Memory Network; the LGBT ${ }^{1}$ Memory and Social Museology Network; the Indigenous Museums Network; the Icapuí (Ceará) Memory Initiatives Network; the Bahian Points of Memory Network; the Southern Bahia Network of Museums and Points of Memory; the Network of Museums, Memory and Social Movement; and Black Social Clubs of Brazil. ${ }^{2}$ The dynamics of these networks are very fluid and a number of other networks are currently being developed. A network of museums and memory concerning povos de terreiros, Afro-Brazilian places of worship, will be created soon.

In addition to these, education networks such as the Museum Educators Networks (REMs) exist in almost all Brazilian states today. These networks bring together people working in museum education sectors as well as museum workers, educators, researchers and other individuals interested in the educational potential of museums, their relationships with formal education and the transformative power of museums for continuous informal education. ${ }^{3}$

The range of experiences is immense and it is preferable to let their protagonists speak for themselves. The best way to become acquainted with these communities, the protagonists of these musealisation processes, is to meet them and hear about their experiences. An external and synthetic view can provide little insight into processes that are as unique as they are complex. This article therefore prioritises data that provide an overview, presenting only a few specific cases outside the major urban centres. The selected case studies are museums or museological processes found outside state capitals that show striking community profiles. They are located in different states and are anchored in three different profiles: the first is an indigenous museum, the second a territorial museum (ecomuseum) and the third is a museum linked to the memory of Afro-Brazilian clubs.

\section{Kanindé Indigenous Museum}

Founded by José Maria Pereira dos Santos, known as Cacique Sotero, the Kanindé Indigenous Museum has been open to the public since 1995. It is located in Sítio Fernandes, Aratuba, $114 \mathrm{~km}$ from Fortaleza, the capital of Ceará. The Cacique himself, the leader of the indigenous group, collected objects, donated the building, organised the space and now works to maintain the museum. Although ethnic unrest was prevalent at this time, the museum was kept secret until 1996, when the Kanindé's land disputes and struggle for recognition became fiercer and the museum was opened to the public (Gomes and Vieira Neto, 2009). According to Gomes and Vieira Neto, this indigenous group is one of the least studied in Ceará, which means that the museum is a highly significant documentation centre. With the support of the Tremembé Mission Association (AMIT), the Kanindé engaged in the local indigenous movement and managed to acquire a differentiated school system - combining formal education with indigenous customs and traditions - and health care through the National Health Foundation (FUNASA). 


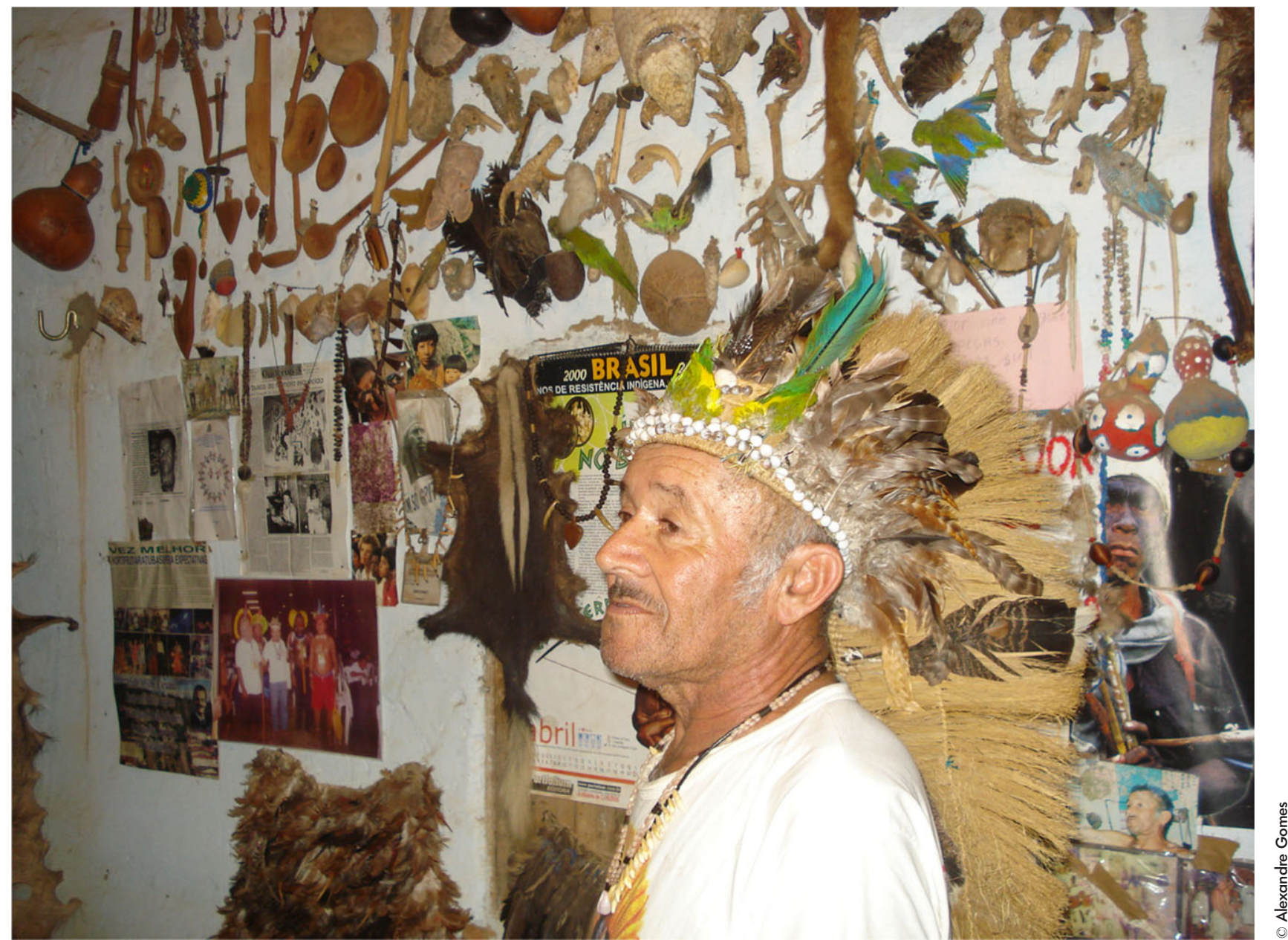

Cacique Sotero at the Kanindé Indigenous Museum

The museum was the first initiative to represent the Kanindé's cultural identity even before the association and the differentiated schooling system were established. The museum received support from the Historiando Project and the Ceará State Museum System in 2009 and was recognised as a Point of Memory ${ }^{4}$ in 2011, having already received the support of the Kanindé Indigenous Association of Aratuba (AIKA), established in 1998. In 2013, the museum was reopened after the renovation and expansion of its premises. This involved the development of themed exhibitions, workshops and roundtable discussions on traditional practices such as flour production, indigenous sporting competitions and body painting parades, among others. A project to document the collection and perform preventive conservation work was carried out by indigenous youth and coordinated by Alexandre Gomes, during the fieldwork undertaken for his master's thesis research (Gomes, 2012). The museum is currently undergoing major expansion with a steering committee consisting of members of the indigenous group, who are highly skilled in generating resources such as the execution of projects that have already won three public awards. 


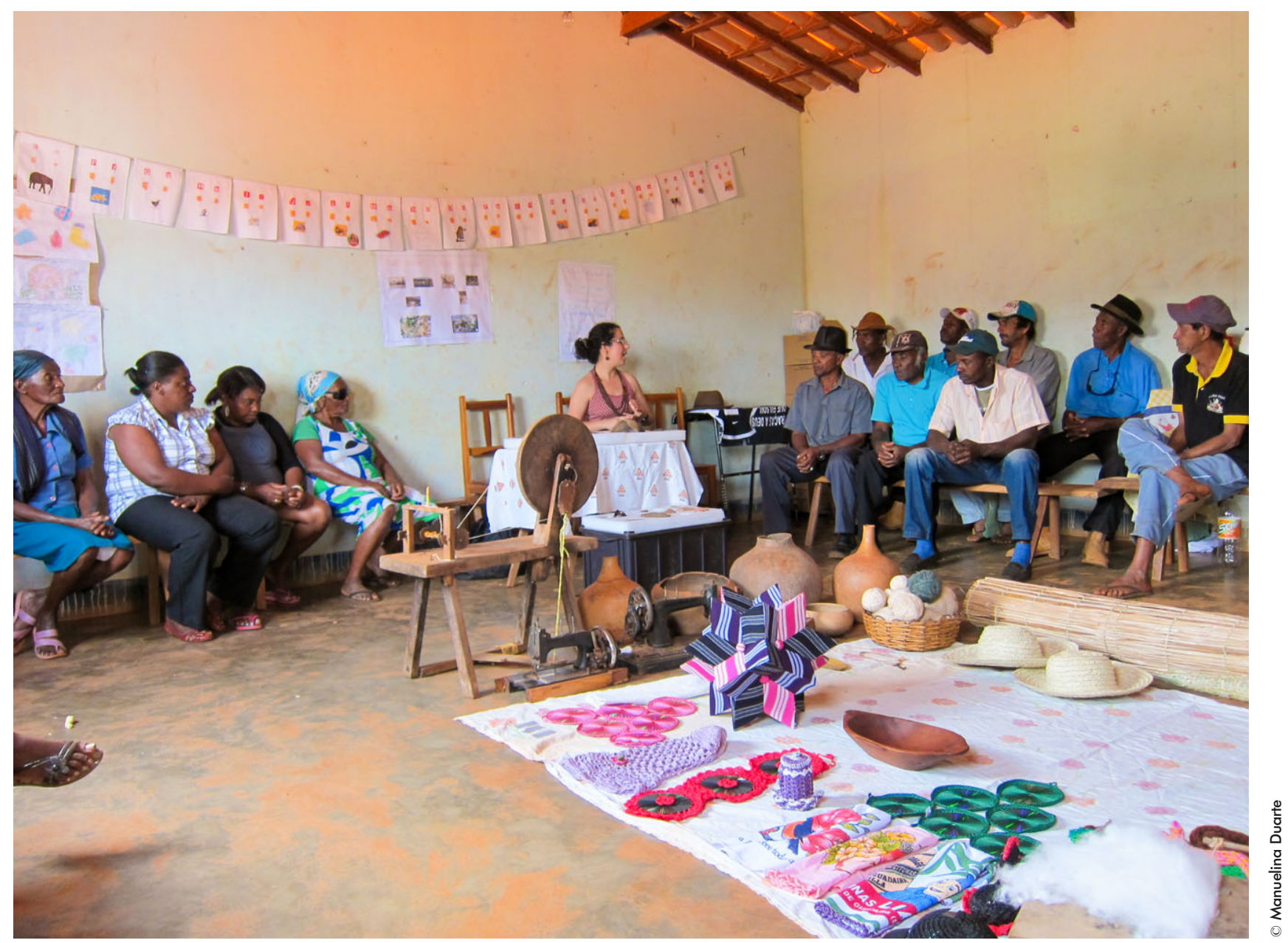

Quilombo community of Pau Ferro do Joazeiro: one of the Museum of the Alto Sertão of Bahia centres

In addition to this museum, other musealisation initiatives by indigenous groups underline the power of the Kanindé people's memory after being defined as 'missing' by the state under the 1850 Land Act. For the state of Ceará, whose historiography 'was born under the sign of the negation of the indigenous presence' (ibid., p. 29), these museums provide important bases for the process of ethnic emergence. ${ }^{5}$

Having first met in 2011, a second training meeting of indigenous museum managers was held in Ceará in 2012, in the Lagoa Encantada indigenous village, a municipality of Aquiraz.
Other experiences of musealisation and memory preservation carried out by indigenous people themselves can be mentioned, such as the Maguta Museum of the Ticuna Indians of Alto Solimões (Benjamin Constant, Amazonas, $1,200 \mathrm{~km}$ from the capital Manaus) and the Museum of the Oiapoque-Kuahí Indigenous Peoples (Oiapoque, Amapá). Without claiming to be exhaustive, museum discourse reviews in public and more traditional institutions in which indigenous groups were consulted and shared in their construction can also be cited. This is the case of the Vanuíre Indian Museum, which is working to create a Kaingang Reference Centre and is developing other initiatives with Guarani, 


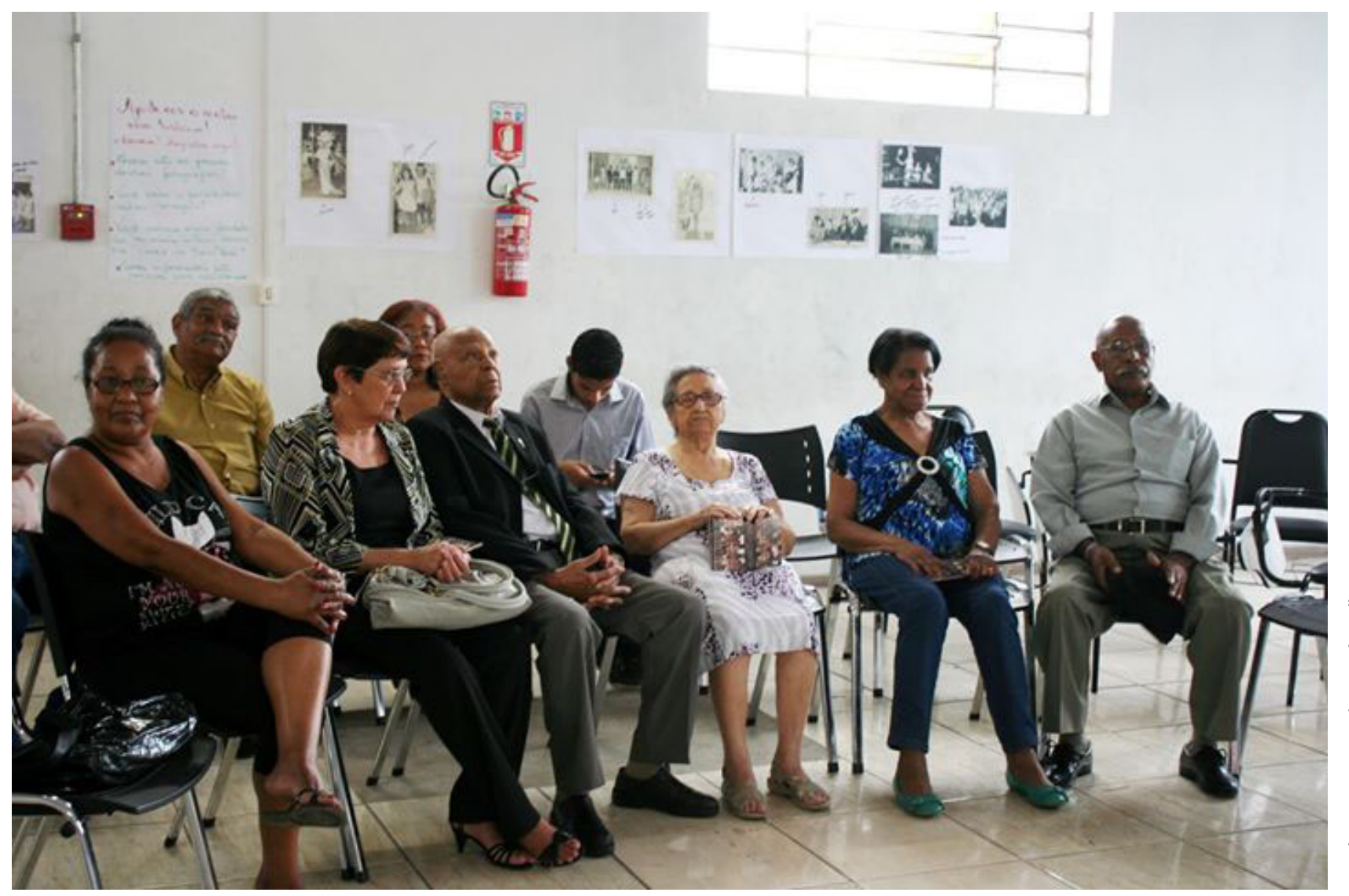

Treze de Maio Museum memory circle, 2010

Krenak and Terena groups (in the city of Tupã, state of São Paulo). In addition, the Anthropological Museum of the Federal University of Goiás (Goiânia) has conducted research and, at the request of the indigenous group, obtained the registration of Karaja dolls as an intangible heritage asset of Brazil in partnership with the Institute of Historic and Artistic Heritage (IPHAN). The Museum of Archaeology and Ethnology of the University of São Paulo has been working with the Assurini Indians of the Xingu to identify pieces in their collection through a range of initiatives in São Paulo, in other collection-holding locations in Campinas, and in various settlements (see Freire, 1999; Vidal, 2008; Cury et al., 2012, among others).

\section{Museum of the Alto Sertão of Bahia (MASB)}

A new territorial museum is being established in an area initially covering the municipalities of Caetité, Guanambi and Igaporã in the Alto Sertão of Bahia. This region, located in the semi-arid Brazilian hinterland, has abundant mineral resources and features caatinga and cerrado landscapes. Inhabited since pre-colonial times, it has a diverse culture that is rich in African, European, indigenous and hinterland traditions. Since 2009, research conducted in the context of environmental impact studies regarding the establishment of wind farms has identified 176 archaeological sites and 389 historic sites, leading to the creation of a collection that has already reached 30,000 
objects (Zanettini Arqueologia, 2013; Moraes, 2013). The population of the municipalities covered by the research took action to keep these heritage artefacts, which were in danger of leaving the region for lack of a museological institution. The energy company responsible under Brazilian legislation for hiring archaeologists and other professionals needed for the heritage recovery work also began to invest in the establishment of the museum.

The establishment of a technical team committed to museum and heritage concepts as a collective undertaking led to the adoption of methodologies under which the museum creation process became community-based, involving 2,376 people and 28 communities in the discussions and the drafting of the MASB museum plans. Over a period of a year and a half, 11 museum training seminars, a series of debates, lectures, short courses and other actions took place (ibid.). A permanent working group exists consisting of participants from the three municipalities. Meeting minutes are always published and the meetings are open to all who wish to participate. This working group takes all decisions that involve or have involved defining the initiative, the site and the name of the museum, and drafts documents such as local by-laws for the creation and regulation of the institution. The building that houses the museum is the Casa da Chácara, a $19^{\text {th }}$ century structure of great significance to the local population. The house is currently being restored and the extensions laid out in the museum's architectural plans are being built. The initiative is still being carried out as a partnership between the technical team, the working group and the communities around both the main site and the 10 museum units that are part of its decentralised activity. These activities are distributed throughout the territory at the headquarters of the Rural Women's Movement; the Pau Ferro Joazeiro quilombo community; the Anísio Teixeira Institute of Education; the municipal school of Caldeiras and the Moita dos Porcos archaeological site in Caetité; rural communities in Curral de Varas and Pajeú do Josefino, Guanambi; the Igaporã Culture Centre; and the Gurunga quilombo community and the Tamboril school in rural Igaporã.

This process was striking because of its community-based initiative. The demand for a museum came from a group of teachers from the municipal schools network of Caetité and the University of the State of Bahia (UNEB), who refused to allow the transfer of archaeological materials to another region and sought help from the local government.

\section{Treze de Maio Museum}

Known as the Treze de Maio Community Museum or simply Treze, the origin of this museum is linked to the old 13 May Railway Cultural Society, ${ }^{6}$ created in 1903 by black employees of the defunct railway of Santa Maria. Black Social Clubs emerged prior to the abolition of slavery in Brazil, as places for socialising in opposition to clubs for white people, from which the black population was banned from entering. Its history is also marked by actions against slavery and racial discrimination, including fundraising for the manumission of enslaved black workers and the funeral and education expenses of its members (Escobar, 2010). Following the example of Santa Maria, clubs of this type were organised in several other Brazilian cities. Today a National Committee of Black Social Clubs exists, formed by representatives from Rio Grande do Sul, Santa Catarina, Paraná, São Paulo, Rio de Janeiro and Minas Gerais. It maps and organises memory and helps to devise 


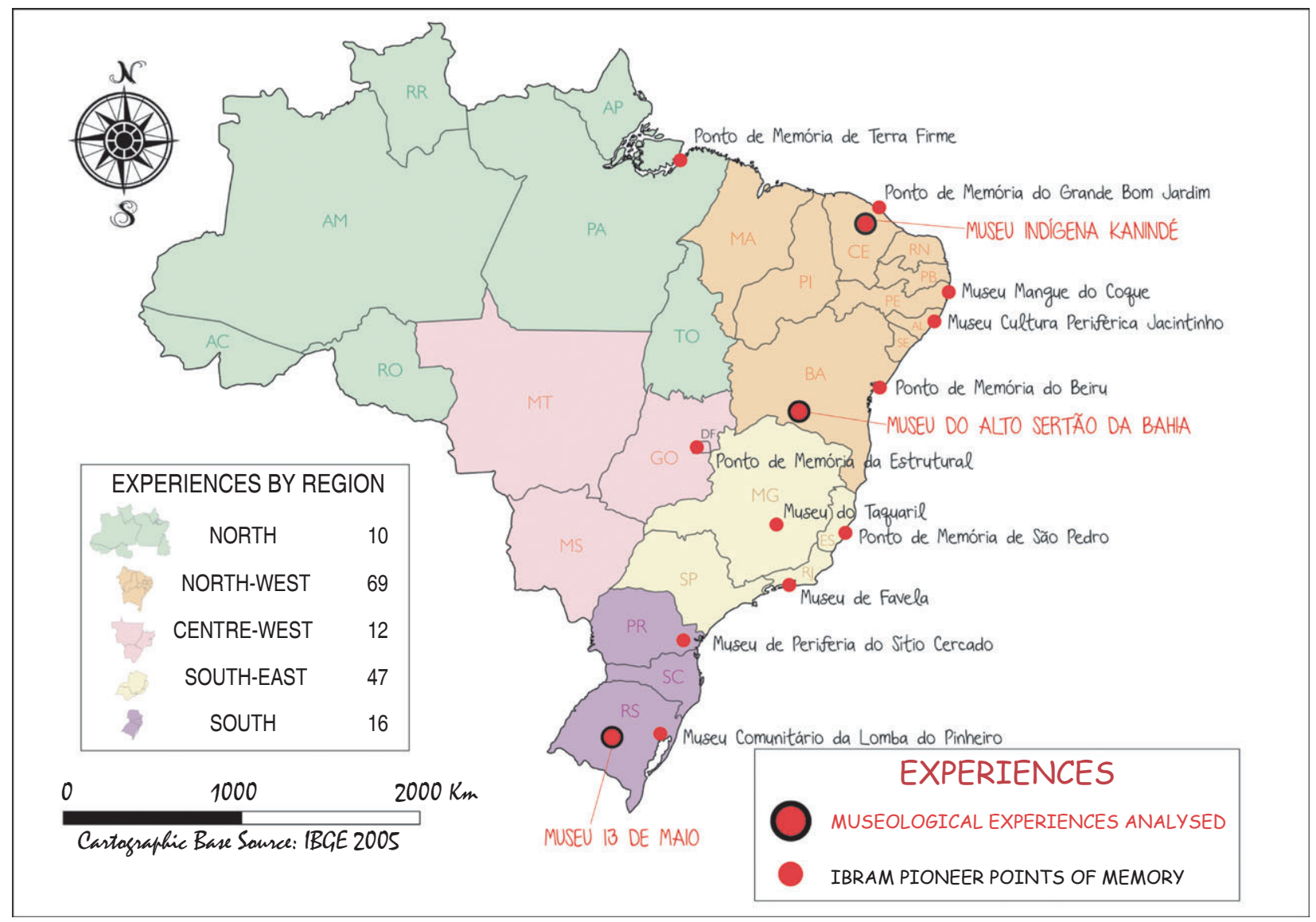

Map of Brazil with the location of the museological experiences analysed and Points of Memory

public policies for the sector (ibid., p. 61). These policies include the creation of a National Museums Register, a portal and an application to the National Institute of Historic and Artistic Heritage (IPHAN) for registration as an intangible Brazilian heritage asset.

Its transformation into a community museum started in 2001, at the initiative of the black community, students in the specialist Museology course at the Franciscan University Centre (UNIFRA) and former members. In 2002 the project was included in the Santa Maria Railway Area Preservation and Revitalization Programme. In 2004, at the initiative of a group mobilised around the creation of the museum, the Treze site was listed as a Municipal Historical Heritage
Site and, shortly thereafter, was included in the state list. The creation process involved restoring and adapting the building and carrying out extensive historical research on the club, including the collection of documents and the production of photographs and testimonials, for instance.

Today the major role of the Treze in the Black Club Movement functions in parallel with the implementation of memory circles, themed exhibitions, African dance, capoeira, samba and percussion workshops. The museum is the meeting venue for various sections of the Black Movement, such as black women's groups, young black university student collectives, African religious groups and others. It aims to promote 
appreciation of black culture and aesthetics, with a special emphasis on women. It is, therefore, a space for resistance against the hegemonic cultural identity of Rio Grande do Sul, commonly associated with German and Italian ancestries.

\section{Points of Memory and others}

The origin of the Points of Memory Programme (2010) was the result of a partnership between different ministry programmes: the Points of Culture Programme of the Ministry of Culture and the National Public Safety and Citizenship Programme (PRONASCI) of the Ministry of Justice, with the support of the Organization of Ibero-American States (OEI). At that time, communities characterised by social vulnerability and violence indicators were prioritised.

The Brazilian Institute of Museums (IBRAM) established 12 pioneer Points of Memory distributed throughout the capitals of the five political administrative regions of the country (north, north-east, centre-west, south and southeast), from nominations by the Ministry of Justice. The $12^{\text {th }}$ Point of Memory selected at the time, in the Brasilândia community of São Paulo, was not continued.
Points of Memory provide methodological support and encouragement for 'initiatives of recognition and appreciation of social memory' (IBRAM, 2011b) which have been developed by different social groups acting to enhance local traditions and ties of belonging based on participatory management. According to Table 1, some Points of Memory are designated as museums, while others are not.

These first Points of Memory were of urban and suburban nature, but their profile was diversified with the opening of the first public tender for the selection of other initiatives in 2011. Submissions were also given by indigenous, quilombo and riverine communities, as well as groups of Gypsy and African descent, and coastal, rural, artistic and gender-based communities.

Points of Memory are now also included in Memory Webs, which are meetings to discuss topics such as social memory and its transformative power. They also devise strategies and share experiences.

Through the call for projects, which was re-launched in subsequent years, as a result of awards or simply registrations, the institute has managed to map more than 150 initiatives

Table 1. Pioneer Points of Memory identified by IBRAM

\begin{tabular}{ll}
\hline Region & \multicolumn{1}{c}{ Experiences } \\
\hline North & Bairro de Terra Firme Point of Memory - Belém/PA \\
North-east & Grande Bom Jardim Point of Memory - Fortaleza/CE \\
& Mangue do Coque Museum Point of Memory - Recife/PE \\
& Suburban Culture Museum - Community of Jacintinho Point of Memory - Maceió/AL \\
& Beiru Point of Memory - Salvador/BA \\
Centre-west & Estrutural Point of Memory - Brasília/DF \\
South-east & Taquaril Museum Point of Memory - Belo Horizonte/MG \\
& Grande São Pedro Point of Memory - Vitória/ES \\
& Pavão-Pavãozinho-Cantagalo Point of Memory (Museu de Favela, MUF) - Rio de Janeiro/RJ \\
South & Sítio Cercado Suburban Culture Museum Point of Memory - Curitiba/PR \\
& Community Museum of Lomba do Pinheiro Point of Memory - Porto Alegre/RS \\
\hline
\end{tabular}

Source: IBRAM 
in Brazil and 18 in Brazilian communities abroad. ${ }^{7}$ The actual number is even greater. At the moment IBRAM is working with data from the most recent call to update the numbers.

In addition to the IBRAM Points of Memory Programme, other initiatives mirror the ideas of sites of memory and memory trails-for instance, the Inventory of Places of Memory of the Atlantic Slave Traffic and of the History of Africans Enslaved in Brazil, which is sponsored by UNESCO with the participation of the Fluminense Federal University (Mattos et al, 2013). In collaboration with researchers, the university has researched and compiled a list of the 100 most significant sites of memory for the slave trade and the history of enslaved Africans in Brazil. The list of 100 items, which clearly is not exhaustive, were divided into seven categories covering a territory between Maranhão and Rio Grande do Sul:

1. Ports of arrival, quarantine and sale sites

2. Illegal landing

3. Candomblé houses, yards and ceremonies

4. Churches and guilds

5. Work and daily life

6. Riots and quilombos

7. Intangible heritage

The pioneering Points of Memory and the three experiments analysed are indicated on the map on page 50 , which also includes the number of initiatives per region which are recognised by IBRAM. This information is currently being updated.
It can be observed that, despite the decentralisation effort, many initiatives are still concentrated in the eastern area of Brazil. Some other initiatives and networks mentioned in the text lie outside this area. To encourage the reader to explore more of the territory of Brazil and to understand our social memory and empowerment practices, a further list is given in Table 2 (p. 53) with a considerable number of initiatives. This list is not intended to be, nor can it be, exhaustive, given the constant emergence of new initiatives. ${ }^{8}$

Some of these museums, ecomuseums and Points of Memory made up an important roadmap of post-conference activities for delegates at the $23^{\text {rd }}$ ICOM General Conference. The roadmap can still be consulted via ABREMC $^{9}$ where websites, blogs and social network profiles for most of them can be found. This article extends the invitation to come and visit them in person.

\section{Acknowledgements}

I wish to thank Aedín Mac Devitt and Hugues de Varine for inviting me to write this article and for their suggestions that enriched the text. On behalf of Adriana Mortara, I would like to thank the Board of ICOM Brazil for its support in taking on this great responsibility. Thank you to friends and those involved in community museums - Alexandre Gomes, João Paulo Vieira Neto, Camila A. de Moraes Wichers, Jean Baptista and Giane Vargas Escobar. Thanks to you all for the basic source materials. On behalf of Cristina Holanda I wish to thank IBRAM for the material provided on the Points of Memory. Thank you to Samuel O. Gomes for his beautiful work on the map of Brazil and to Nei Clara de Lima for reading the original. 
Table 2. A compiled list of initiatives

\begin{tabular}{|c|c|}
\hline Region & Experiences \\
\hline North & $\begin{array}{l}\text { Amazônia Ecomuseum (Belém, PA) } \\
\text { Sacaca Museum (Macapá, AP) }\end{array}$ \\
\hline North-east & $\begin{array}{l}\text { Casa de Izidória Lopes Memory Point (Catanhede, MA) } \\
\text { Divino de Porto Grande Community Memorial Museum (São Luiz, MA) } \\
\text { Community Museum of Popular Culture Drums and Maracás (São Luiz, MA) } \\
\text { Graciliano Ramos Community Ecomuseum (Tabuleiro dos Martins, AL) } \\
\text { Casa do Samba de Dona Dalva (Cachoeira, BA) } \\
\text { Recôncavo Baiano Live Culture Memorial (Cachoeira, BA) } \\
\text { Coroa Vermelha Indigenous Museum (Santa Cruz de Cabrália, BA) } \\
\text { Arca do Axé Memory Centre (Salvador, BA) } \\
\text { Mãe Mirinha do Portão Community Museum (Lauro de Freitas, BA) } \\
\text { Olho do Tempo Living Museum (Joao Pessoa, PB) } \\
\text { Camará Memory Point (Camaragibe, PE) } \\
\text { Estrela de Ouro Memory Point (Recife, PE) } \\
\text { Maranguape Ecomuseum (Maranguape, CE) } \\
\text { Z8 Fishermens' Colony (Fortaleza, CE) } \\
\text { Titãnzinho Residents Association (Fortaleza, CE) } \\
\text { Dias Macedo Social Memory Point (Fortaleza, CE) } \\
\text { Moura Brasil Community (Fortaleza, CE) } \\
\text { Natural Ecomuseum of Mangue (Fortaleza, CE) } \\
\text { Pitaguary Indigenous Museum (Maracanaú, CE) } \\
\text { Miniature Museum (Tauá, CE) } \\
\text { Caetanos de Cima Community Memorial (Amontada, CE) } \\
\text { Caldeirão NGO (Crato, CE) } \\
\text { Serra do Evaristo Community Museum (Baturité, CE) } \\
\text { Santana do Acaraú Parish Memorial (Santana do Acaraú, CE) } \\
\text { Prainha do Canto Verde Memorial (Amontada, CE) }\end{array}$ \\
\hline Centre-west & $\begin{array}{l}\text { Candanga Living Memory Museum (Brasília, DF) } \\
\text { Ferreiro Ecomuseum (Goiás, GO) }\end{array}$ \\
\hline South-east & $\begin{array}{l}\text { Serra de Ouro Preto Ecomuseum (Ouro Preto, MG) } \\
\text { Urban Quilombos and Favelas Museum - MUQUIFU (Belo Horizonte, MG) } \\
\text { Morro da Carapina/Cidade do Futuro Memory Point (Gov. Valadares, MG) } \\
\text { Capixaba do Negro - MUCANE Museum (Vitória, ES) } \\
\text { Duque de Caxias Living Museum (Duque de Caxias, RJ) } \\
\text { Manguinho Ecomuseum (Rio de Janeiro, RJ) } \\
\text { Horto Museum (Rio de Janeiro, RJ) } \\
\text { Museu da Maré (Rio de Janeiro, RJ) } \\
\text { Santa Cruz Ecomuseum (Rio de Janeiro, RJ) } \\
\text { Sepetiba Ecomuseum (Rio de Janeiro, RJ) } \\
\text { Bangu Museum (Rio de Janeiro, RJ) } \\
\text { Sankofa Museum (Rocinha, Rio de Janeiro, RJ) } \\
\text { Sapukai Village - Guarani Sapukai People (Angra dos Reis, RJ) } \\
\text { Ilha Grande Ecomuseum - Prison Memorial (Angra dos Reis, RJ) } \\
\text { São José dos Campos Folklore Museum (São José dos Campos, SP) } \\
\text { Lins Historical and Archaeological Museum (Lins, SP) } \\
\text { Ibaô Culture and Memory Point (Campinas, SP) }\end{array}$ \\
\hline South & $\begin{array}{l}\text { Itaipu Ecomuseum (Foz do Iguaçu, PR) } \\
\text { Roda de Memória Memory Point (Londrina, PR) } \\
\text { Apucaraninha Indigenous Land (Tamarana, PR) } \\
\text { Engenho do Sertão Community Museum (Bombinhas, SC) } \\
\text { Missioneira Memory Point (São Miguel das Missões, RS) } \\
\text { São Leopoldo Memory Point (São Leopoldo, RS) } \\
\text { TV OVO Memory Point (Santa Maria, RS) } \\
\text { Ilha da Pólvora Ecomuseum (Rio Grande, RS) } \\
\text { Picada Café Route Community Museum (Picada Café, RS) }\end{array}$ \\
\hline
\end{tabular}




\section{Notes}

1. Lesbian, Gay, Bisexual and Transgender.

2. Access to the sites and blogs of these networks can be a first step in understanding the diversity of experiences and in planning a visit itinerary: Brazilian Association of Ecomuseums and Community Museums (ABREMC) (http:// www.abremc.com.br/); Ceará Network of Community Museums (RCMC) (http://museuscomunitarios.tumblr.com/); Rio Grande do Sul Network of Points of Memory, and Memory and Social Museology Initiatives (REPIM-RS) (http://redepontors.blogspot.com.br/); Rio Grande do Norte of Points of Memory Network, the Pará Points of Memory Network, the LGBT Memory and Social Museology Network (http://redelgbtmemoriamuseologia.blogspot.com.br/) which has launched calls for papers for the third issue of its journal; Indigenous Museums Network; Icapui (CE) Memory Initiatives Network; Bahian Points of Memory Network; Museums, Memory and Social Movement Network (http://redemuseusmemoriaemovimentossociais.blogspot. com.br/); and Black Social Clubs of Brazil (http://www. clubessociaisnegros.com.br/).

3. REMs exist in almost every state in Brazil. In general their activities consist of face-to-face meetings for discussions and lectures, seminars, organising internet discussion group lists, and possibly publications. Almost all of these networks have websites or blogs such as Museum Educators Networks of Goiás (REM-Goiás) (http://remgoias.blogspot.com.br/); Museum Educators Networks of Rio de Janeiro (REM/RJ) (http://remrj. blogspot.com.br/); Museum Educators Networks of Ceará REM-CE (REM-CE) (http://rem-ce.blogspot.com.br/); Museum and Cultural Institution Educators Networks (REMic) (http://remic-pe.blogspot.com.br/); Museum Educators Networks of Bahia (REM/BA) (http://rem-bahia. blogspot.com.br/); Museum Educators Networks of Rio Grande do Sul (REM-RS) (http://remrgs.blogspot.com.br/); Museum Educators Networks of Paraíba (REM-PB) (http:// remparaiba.blogspot.com.br/); Museum and Cultural Institution Educators Networks of the Federal District (REMIC-DF) (http://remic-df.blogspot.com.br/); Museum, Cultural Institution and Historic Building Educators Networks of the State of São Paulo (REM-SP) (http:// remsp.blogspot.com.br/); Museum and Heritage Educators Networks of Mato Grosso (REMP-MT) (https://www. facebook.com/rempmtcuiaba); Museum Educators Networks of Santa Catarina (REM/SC) (http://remsc.blogspot.com.br/); Museum Educators Networks of Sergipe (REM-SE) (http:// rem-sergipe.blogspot.com.br/).
4. Recognition as a Point of Memory is defined through the Ministry of Culture's programme Pontos de Memória, which supports initiatives recognising and enhancing social memory. It is part of a bigger programme called Pontos de Cultura (Points of Culture), which was conceived by ex-Minister Gilberto Gil in reference to do-in, a Chinese massage therapy technique.

5. The Cacique-Perna-de-Pau of the Tapeba Memorial in Caucaia, built in 2005; the Jenipapo-Kanindé Indigenous Museum in Aquiraz (2010); the Oca da Memória, organised from 2008 by the Kalabaça and the Tabajara in Poranga; the Abanaroca (Indian House) of the Potyguara/Gavião/Tabajara/ Tubiba-Tapuia in the municipality of Monsenhor Tabosa; the Support House of the Pitaguary in Monguba (Pacatuba); the first site of the Maria Venância School in Almofala (Itarema), preserved by the Tremembe (Gomes and Vieira Neto, 2009, p. 19) and the museum of the Kariri in Cratéus.

6. The name Treze de Maio (13 May) is a reference to the date of Princess Isabel's signing of the Golden Law, which abolished slavery in Brazil. Other clubs have also adopted the name Princess Isabel, thus legitimising the people and events of the royalist era and creating a more complex interplay between resistance and reverence, memory and forgetting.

7. Data presented at the ICOM $23^{\text {rd }}$ General Conference, August 2013.

8. Initiatives in regions where networks exist were more easily mapped and may, therefore, dominate the list numerically.

9. http://www.abremc.com.br/pdf/QuadroABREMCPortICOM2013.pdf

\section{References}

Brazilian Association of Museums and Community Ecomuseums [ABREMC]. http://www.abremc.com.br/ [Accessed 23 October 2013].

Chagas, Mário. 2011. Museus, memórias e movimentos sociais. Lusophone University of Humanities and Technologies (ed.), Questões Interdisciplinares na Museologia. Cadernos de Sociomuseologia, Vol. 41. Lisbon, Lusophone University of Humanities and Technologies, pp. 5-15.

Cury, Marília Xavier, Vasconcellos, Camilo de Mello and Ortiz, Joana Montero (coords.). 2012. Questões indígenas e 
museus: debates e possibilidades. Brodowski, ACAM Portinari: Museu de Arqueologia e Etnologia da USP: Secretaria de Estado da Cultura (SEC). (Museu Aberto Collection).

Davis, Peter. 1999. Ecomuseums - A sense of place. London, New York, Leicester University Press.

Duarte Cândido, Manuelina Maria. 2014. Gestão de museus, um desafio contemporâneo: diagnóstico museológico e planejamento. Porto Alegre, Medianiz.

Duarte Cândido, Manuelina Maria and Lima, Nei Clara de. 2014. Ocupe o Museu (com) Memórias de Goiânia: o público como construtor de conteúdos de museu e a participação biográfica na cidade e no museu. MIDAS Museus e Estudos Interdisciplinares, No. 3. p. 12. http:// midas.revues.org/505

Escobar, Giane Vargas. 2010. Clubes Sociais Negros: lugares de memória, resistência negra, patrimônio e potencial. Santa Maria, UFSM. (Professional Master's Dissertation in Cultural Heritage).

Escobar, Giane Vargas, Varine, Hugues de. 2013. Patrimônio comunitario e novos museus: a face afro-brasileira da museologia comunitária. Baptista, Jean. and Silva, Claudia Feijó da (coords.). Práticas Comunitárias e Educativas em Memória e Museologia Social. Rio Grande, Editora da FURG.

Freire, José R. Bessa. 1999. A descoberta do museu pelos índios. University of Brasília (ed), Terra das Águas - Revista semestral do Núcleo de Estudos Amazônicos da Universidade de Brasília. http://pt.scribd.com/doc/58829252/

A-Descoberta-Do-Museu-Pelos-Indios [Accessed 24 October 2013].

Gomes, Alexandre Oliveira. 2012. Aquilo é uma coisa de índio: objetos, memória e etnicidade entre os Kanindé do Ceará. Recife, Federal University of Pernambuco. (Master's Dissertation in Anthropology).

Gomes, Alexandre Oliveira and Vieira Neto, João Paulo. 2009. Museus e memória indígena no Ceará: uma proposta em construção. Fortaleza, Secult.

IBRAM. 201la. Museus em Números. Brasília, IBRAM. http:// www.museus.gov.br/wp-content/uploads/2011/11/ museus_em_numeros_volumel.pdf [Accessed 26 October 2013].

IBRAM. 2011b. Programa Pontos de Memória (Points of Memory Programme). Brasília, IBRAM. http://www.museus. gov.br/programa-pontos-de-memoria/ [Accessed 25 October 2013].

Mattos, Hebe., Abreu, Martha and Guran, Milton. 2013. Inventário dos Lugares de Memória do Tráfico Atlântico de
Escravos e da História dos Africanos Escravizados no Brasil. Laboratory of Oral History and Image (LABHOI) of the Fluminense Federal University/International Scientific Committee of the UNESCO Slave Route Project: Resistance, Liberty, Heritage. April, 2013. http://www.seppir.gov.br/ arquivos/inventario-dos-lugares-de-memoria-do-trafico [Accessed 24 October 2013].

Moraes, Camila. 2013. A construção coletiva do Museu do Alto Sertão da Bahia: o planejamento museológico como processo educativo e de mudança social. Rio de Janeiro, CECA/ICOM. (Presentation to the $23^{\text {rd }}$ ICOM General Conference).

Peirano, Marisa. 1999. Antropologia no Brasil (alteridade contextualizada) S. Miceli, (coord.) (ed), O que ler na ciência social brasileira (1970-1995). São Paulo, Editora Sumarél ANPOCS, pp. 225-266.

Van Mensch, Peter. 1992. Towards a Methodology of Museology. Zagreb, University of Zagreb. (Doctoral thesis).

Varine, Hugues de. 2012. As raízes do futuro: o patrimônio a serviço do desenvolvimento local. Porto Alegre, Medianiz.

Varine, Hugues de. 2013. O museu comunitário é herético? 16 May, 2015. ABREMC website. http://www.abremc.com.br/ artigosl.asp?id=9 [Accessed 23 October 2013].

Vidal, Lux Boelitz. 2008. O Museu dos Povos Indígenas do Oiapoque-Kuahí: gestão do patrimônio cultural pelos povos indígenas do Oiapoque, Amapá. M. C. O. Bruno and K. R. F. Neves (coords.) (eds.), Museus como agentes de mudança social e desenvolvimento propostas e reflexões museológicas. São Cristóvão, Museu de Arqueologia de Xingó, pp. 173-81.

Zanettini Arqueologia (Technical team: Bernardo de Carvalho, Camila A. de Moraes Wichers, Louise Prado Alfonso, Manuelina Maria Duarte Cândido, Paulo Zanettini). 2013. Plano Museológico do MASB. São Paulo, Zanettini Arqueologia. 